\title{
Immunohistochemical and biochemical study of the effect of Rheum ribes on the pancreas of diabetic rats
}

\begin{tabular}{ccc}
\hline Kawa F. Dizaye $^{1 *}$ & Afrah H. Sultan $^{2}$ & Hiwa B. Banna $^{2}$ \\
\hline Abstract \\
\end{tabular}

Background and objective: Reports indicate that Rheum ribes has antihyperglycemic effects. This study aimed to find out the hypoglycemic effects of aqueous extract of Rheum ribes on the pancreatic tissue of diabetic male rats and compare the results of both histological and biochemical findings with that of metformin.

Methods: Thirty-two albino male rats were divided into four groups with eight animals for each group; $1^{\text {st }}$ group as normal control, $2^{\text {nd }}$ group as alloxan induced diabetics, $3^{\text {rd }}$ group as diabetic treated with Rheum ribes, and $4^{\text {th }}$ groups as diabetic treated with Metformin. The body weight and fasting blood glucose levels of all the rats were recorded at weekly intervals during the experimental period. Biochemical, histochemical, and immunohistochemical investigations were used.

Results: Diabetic rats showed a decrease in serum amylase with marked elevation in blood glucose level. Histological examination of the pancreas from diabetic rats revealed an increase in the thickness of the basement membrane of the blood vessels and capillaries in islets of Langerhans, as well as decreased activity of Beta-cells and increase the activity of Alpha and Delta cells using both Periodic Acid Schiff stain and immunohistochemistry techniques. Administration of aqueous extract of Rheum ribes caused significant and dramatic changes in most of the parameters measured in this study, including an increase in serum amylase, and lowering the level of blood glucose, in comparison to the diabetic group.

Conclusion: Daily administration of Rheum ribes significantly reduced blood glucose and caused a marked increase in the activity of Beta-cells, followed by a decrease in the activity of Alpha-cells. The results of tissue structures and serum biochemical estimation indicated that the plant extract has regeneration and repair effects.

Keywords: Alloxan; Diabetic rats; Rheum ribes; Pancreatic tissues; Metformin.

\section{Introduction}

Traditional medicines continue to form the mainstay of treatment in more remote and underdeveloped areas where conventional medicines are unavailable, or unaffordable. ${ }^{1}$ Plant derivates with hypoglycemic properties have been used in folk medicine and traditional healing systems around the world. ${ }^{2,3}$ Although herbal medicines have long been used effectively in treating diabetes mellitus, the mechanisms of most of the herbs used have not been defined. Many investigations of oral anti-hyperglycemic agents of plant origin used in traditional medicine have been conducted, and many of the plants show positive activity. ${ }^{4}$ Although there are suggestions about the mechanism of action of plants, the exact mechanism is unclear. Rheum ribes (Rhubarb) root is one of the oldest and best-known Chinese herbal medicines. ${ }^{5}$ It has been indicated that a decoction extract of Rheum ribes roots possesses a significant hypoglycemic effect and blood sugar lowering activity in alloxan induced diabetic mice. ${ }^{6,7}$ There are

${ }_{1}^{1}$ Department of Pharmacology, College of Medicine, Hawler Medical University, Erbil, I raq.

2 Department of Anatomy and Histology, College of Medicine, Hawler Medical University, Erbil, I raq.

* Correspondence: kawa.dizaye@hmu.edu.krd 
no published studies on the effect of aqueous extract of rhubarb roots on histology of the pancreas. Therefore, we studied the histological as well as some biochemical changes in the pancreas in normal and in diabetic rats before and after oral administration of the aqueous extract of this plant.

\section{Methods}

\section{Animals and housing}

Healthy, adult male albino rats of Wister strain weighing approximately (200-290) gm were used in the present study. The animals were housed at the animal house of College of Medicine, Hawler Medical University, under standard laboratory conditions (12 hours light: 12 hours dark photoperiod, $22 \mathrm{C}^{\circ}{ }_{ \pm} 2 \mathrm{C}^{\circ}$ ). They were given standard pellets and tap water.

Preparation of the aqueous plant extracts

An aqueous extract of rhubarb root was prepared by the method of decoction. ${ }^{8}$

Induction of experimental diabetes

Diabetes was induced by a single intraperitoneal injection of alloxan monohydrate $(100 \mathrm{mg} / \mathrm{kg})(\mathrm{BDH}$ Chemical Ltd. England). ${ }^{9}$

\section{Experimental design}

Forty-two rats were divided into seven groups, each consisting of six rats, to study the effect of aqueous extract of rhubarb roots for 14 and 30 days:

Group I: Normal control rats given distilled water

Group II: Normal rats treated with rhubarb roots for 30 days

Group III: Diabetic control rats given distilled water for 14 days.

Group IV: Diabetic control rats given distilled water for 30 days.

Group V: Diabetic rats given aqueous extract of rhubarb roots for 14 days

Group VI: Diabetic rats given aqueous extract of rhubarb roots for 30 days

Group VII: Diabetic rats given metformin for 30 days.

The body weight and fasting blood glucose levels of all the rats were recorded at regular intervals (every week) during the experimental period.

\section{Sampling and biochemical analysis}

After 14 days and 30 days of oral administration of the extract, the animals were fasted overnight and anesthetized with chloroform, and blood was drawn by cardiac puncture into a plastic syringe. The serum obtained was used for biochemical tests.

\section{Preparation of tissue samples}

At day 14 and 30 of oral administration of plant extract, samples of the pancreas were removed from the sacrificed animals. All samples were fixed in Bouin's solution for 24 hours, and then the samples were processed by light microscopy. Tissue blocks of pancreas were cut at 5 microns' thickness by an electronic microtome. Sections were mounted on glass slides and stained by

1- Special stain PAS (Periodic Acid Schiff).

2- Immunohistochemistry (IHC) (antiinsulin, anti-glucagon, and antisomatostatin)

\section{Method of IHC staining}

The Dako CytomationEnVision ${ }^{\circledR}+$ Dual link system-HRP (DAB+) staining protocol was followed for immunostaining to detect insulin and glucagon expression, which was applied to Bouin's-fixed, paraffin embedded tissues.

Counting per unit length and Histological measurements

A calibration stage micrometer was used for examination, measurement, and calculation of the PAS stain histological sections of the pancreas, to measure the thickness of the basement membrane.

\section{Scoring of immunostaining}

Positive expression of immunostaining gives clear cut cytoplasmic staining of brown color with DAB. The cells were calculated by the special computerized method called grid cell count. Positive cells were determined by counting 1000 cells. All significantly stained cells were considered positive and divided by 10 
to acquire the percentage (immunostaining index); at least 10 HPFs were measured for each case for the purpose of scoring. ${ }^{10}$

Scoring of immunostaining was assessed as follows:

Negative: when the index was $<5 \%$.

Mild positive: when the index was $>5 \%$ and $<20 \%$.

Moderate positive: when the index was $>20 \%$ and $<50 \%$.

Strong positive: when the index was $>50$.

\section{Statistical analysis}

All results were expressed as means \pm standard error of means ( $\mathrm{M} \pm \mathrm{SEM})$, and statistical analysis was carried out using the statistical package for the social sciences (version 21). Data analysis was made using one-way analysis of variance
(ANOVA). The comparison among groups was made using the Duncan test. A $P$ value of $<0.05$ was considered statistically significant. The experiments were carried out with the approval of the ethics committee of the College of Medicine, Hawler Medical University.

\section{Results}

Compared to the control group, the level of blood glucose in alloxan-induced diabetic rats was significantly increased at the $14^{\text {th }}$ and $30^{\text {th }}$ days. Whereas, the level of serum amylase and the body weight in alloxan-induced diabetic rats were significantly decreased at the $14^{\text {th }}$ and $30^{\text {th }}$ days as compared to the control group, as shown in Tables 1 and 2.

Table 1: The effects of $200 \mathrm{mg} / \mathrm{kg}$ of Rhubarb (PO) on body weight and biochemical tests in normal and alloxan induced diabetic rats.

\begin{tabular}{lcccccc}
\hline Treatments & C & TND & DC & TD & DC & TD \\
& & 30 days & 14 days & 14 days & 30 days & 30 days \\
\hline Glucose $(\mathrm{mg} / \mathrm{dl})$ & $97.7 \pm 6.6$ & $104.7 \pm 5$. & $248.3 \pm 21$ & $146.5 \pm 11$. & $303 \pm 40.7$ & $136.7 \pm 9.4$ \\
& $\mathrm{a}$ & $\mathrm{a}$ & $\mathrm{b}$ & $\mathrm{a}$ & $\mathrm{b}$ & $\mathrm{a}$ \\
Amylase $(\mathrm{IU} / \mathrm{L})$ & $756.5 \pm 66$ & $941 \pm 76$ & $349 \pm 31.7$ & $648.5 \pm 81$. & $411.5 \pm 36$ & $944.5 \pm 59$ \\
& $\mathrm{~b}$ & $\mathrm{~b}$ & $\mathrm{a}$ & $\mathrm{b}$ & $\mathrm{a}$ & $\mathrm{b}$ \\
Body weight $(\mathrm{gm})$ & $258.3 \pm 6$. & $264.2 \pm 6$ & $206.5 \pm 3$. & $213.3 \pm 4.4$ & $191.7 \pm 3.3$ & $224.2 \pm 5.3$ \\
& $\mathrm{~b}$ & $\mathrm{~b}$ & $\mathrm{a}$ & $\mathrm{a}$ & $\mathrm{a}$ & $\mathrm{c}$ \\
\hline
\end{tabular}

$\mathrm{C}=$ Control, TND =Treated Non Diabetic Rats, DC =Diabetic Control, TD =Treated Diabetic Rats Similar letters indicate no significant differences.

* Different letters indicate significant differences at $P<0.05$.

Table 2: The effects of $100 \mathrm{mg} / \mathrm{kg}$ of Metformin on body weight and biochemical tests in normal and alloxan induced diabetic rats.

\begin{tabular}{lccccc}
\hline Treatments & C & TND & DC & DC & TD \\
& & 30 days & 14 days & 30 days & 30 days \\
\hline Glucose $(\mathrm{mg} / \mathrm{dl})$ & 97.7 & 114.3 & 248.33 & 303.8 & 139.5 \\
& \pm 6.68 & \pm 4.79 & \pm 21.35 & \pm 40.70 & \pm 19.43 \\
Amylase $(\mathrm{IU} / \mathrm{L})$ & $\mathrm{a}$ & $\mathrm{a}$ & $\mathrm{b}$ & $\mathrm{b}$ & $\mathrm{a}$ \\
& 756.5 & 735 & 349 & 411.5 & 820.6 \\
& \pm 66.77 & \pm 91.12 & \pm 31.73 & \pm 36.02 & \pm 126.57 \\
Body weight $(\mathrm{gm})$ & $\mathrm{b}$ & $\mathrm{b}$ & $\mathrm{a}$ & $\mathrm{a}$ & $\mathrm{b}$ \\
& 258.3 & 273.3 & 206.5 & 191.7 & 236.7 \\
& \pm 6.1 & \pm 6.72 & \pm 3.94 & \pm 3.3 & \pm 4.01 \\
& $\mathrm{C}$ & $\mathrm{C}$ & $\mathrm{a}$ & $\mathrm{a}$ & $\mathrm{b}$ \\
\hline C = Control, TND = Treated Non Diabetic Rats, DC =Diabetic Control, TD $=$ Treated Diabetic Rats
\end{tabular}


Effect of aqueous extract of Rheum ribes on the biochemical tests in normal and alloxan-induced diabetic rats

Following the treatment of diabetic animals with aqueous extract of rhubarb roots at day $14^{\text {th }}$ and $30^{\text {th }}$ of the administration, significant reduction was recorded in the values of blood glucose, while the level of serum amylase was increased considerably. Also, there was some gain in the body weight compared to the control group. Similar results were also obtained after the administration of Metformin to diabetic animals. No significant changes were recorded when rubarb roots extract, or Metformin used in healthy nondiabetic controls (Tables 1 and 2). Compared to the control group, the measurements of the thickness of the basement membrane in the blood vessel and capillaries in alloxan-induced diabetic rats were significantly increased on the $14^{\text {th }}$ and $30^{\text {th }}$ days, as shown in Tables 3 and 4 and Figure $1(A, B, C)$. The thickness of the basement membrane of capillaries in the islets of Langerhans was significantly greater in diabetic animals on the $30^{\text {th }}$ day. $A$ reduction in the thickness of the basement membrane in blood vessels in the pancreas and of capillaries in the islet of Langerhans was found in diabetic rats treated with both (Rheum ribes extract and Metformin) at the $14^{\text {th }}$ and $30^{\text {th }}$ days. These improvements were more pronounced at day $30^{\text {th }}$ of the treatment when compared with diabetic controls (Tables 3 and 4 and Figure $1 \mathrm{D}, \mathrm{E}, \mathrm{F})$. No significant changes were found in treated nondiabetic rats at the $14^{\text {th }}$ and $30^{\text {th }}$ days with both (Rheum ribes extract and Metformin) when compared to the control group.

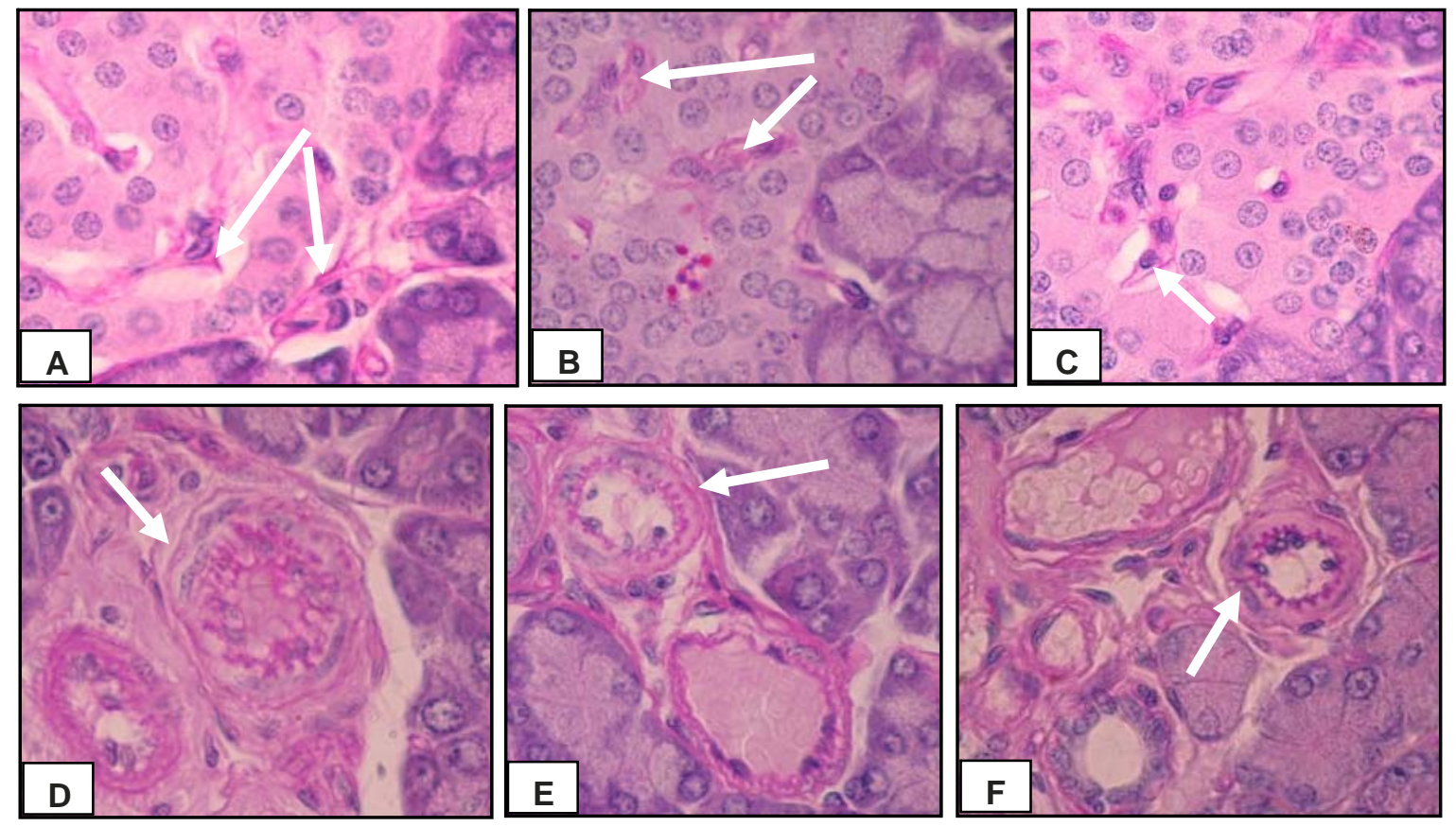

Figure 1: Pancreatic tissue of rats:

A: section through islet of Langerhans showing few capillaries and their basement membrane (arrows) from the pancreas of a normal animal. Stained with (PAS) 1000x..

B: Thickened basement membrane of islet capillary (arrows) in diabetic pancreas stained with (PAS) 1000x. C: section through islet of the pancreas from diabetic animal showing reduce the thickness of the capillary basement membrane (arrow.) after treatment with Rheum ribes extract stained with (PAS) 1000x. $\mathrm{D}$ : section shows arterioles inside the exocrine part of the gland with normal distinct basement membrane (arrow) in normal pancreas stained with (PAS) 1000x.

E: Thickened arteriole basement membrane (arrow) in diabetic pancreas stained with (PAS) 1000x.

$\mathrm{F}$ : section, shows reduced thickness of arteriole basement membrane arrows) after treatment with Rheum ribes extract stained (PAS). 1000x 
Histological changes in the pancreas of diabetic animals using PAS and H\&E staining methods.

A significant reduction in the activity of beta cells were found in diabetic rats compared to normal animals, while after treatment with (Rheum ribes extract) on $14^{\text {th }}$ and $30^{\text {th }}$ days, most activities were restored as compared to the diabetic control, it was improved but not up to the normal range when compared to the control group (Figure $2 \mathrm{~A}, \mathrm{~B}, \mathrm{C}$ ). There was no much difference in the activity of beta cells observed in diabetic rats treated with
Metformin on $14^{\text {th }}$ and $30^{\text {th }}$ days as compared to diabetic controls (Tables 3 and 4). A significant reduction in the activity of alpha cells were found in diabetic rats treated with both (Rheum ribes extract and Metformin) on $14^{\text {th }}$ and $30^{\text {th }}$ days as compared to the diabetic controls but not up to return to normal range as compared to the control group (Tables 3 and 4 and Figure 2 (D, E, F)). No significant changes were recorded in treated nondiabetic rats at $14^{\text {th }}$ and $30^{\text {th }}$ days both (Rheum ribes extract and metformin) groups when compared to the control group.
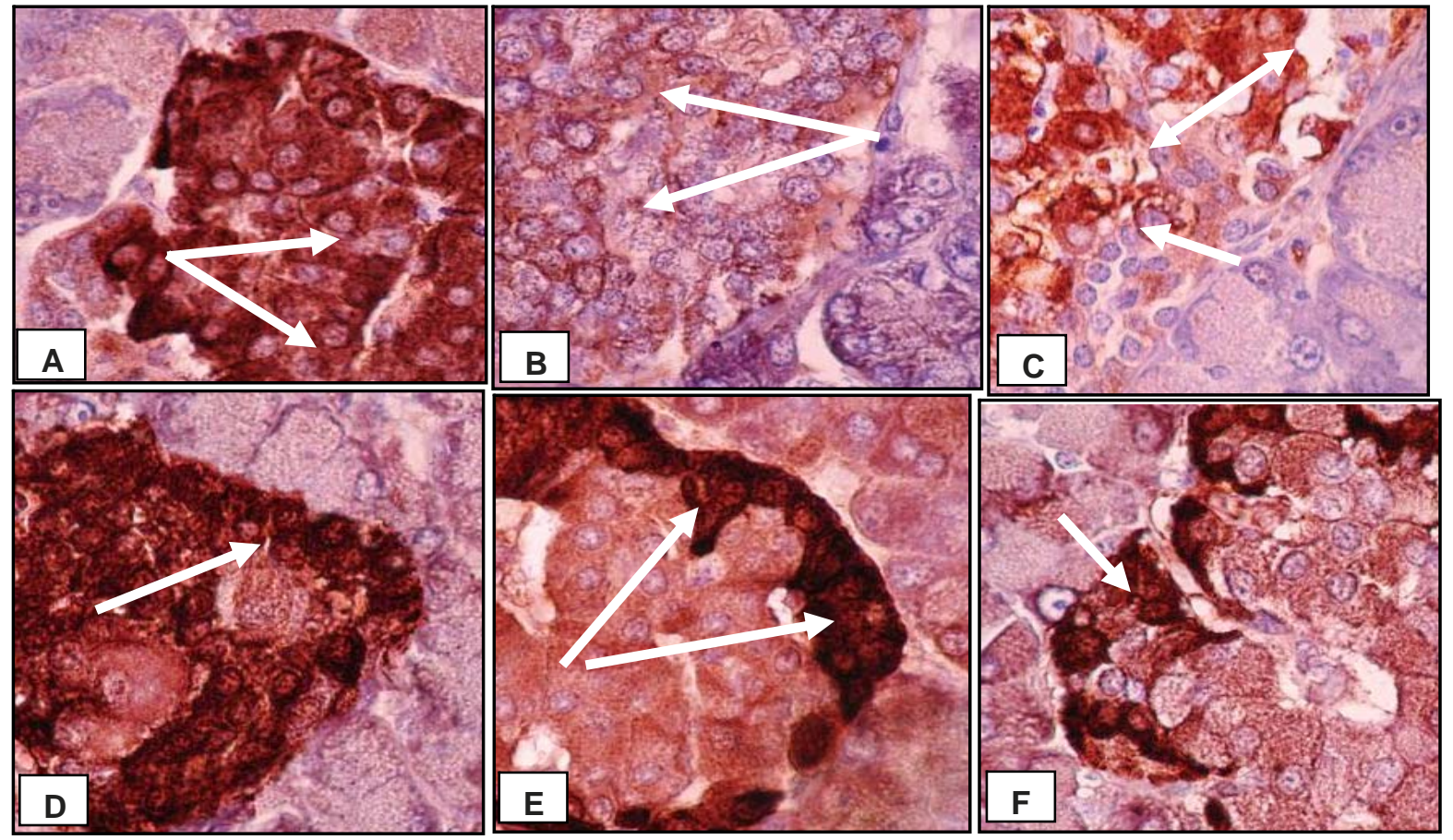

Figure 2: Pancreatic tissue of rats:

A: section through islet of the pancreas from normal animal stained with anti insulin antibodies for B cell identification. (Arrows) (IHC stain) using DAP chromogen. 1000x

$B$ : the pancreas of a diabetic animal showing marked reduction in the activity of insulin inside the Beta cell (arrows). (IHC stain) using DAP chromogen. 1000x

C: section through islet of diabetic animal showing restored activity of the B cell (arrows) after treatment with Rheum ribes extract using (IHC stain) and DAP chromogen. 1000x

D: using antiglucagon antibodies for localization of glucagon inside A cell of normal pancreas (arrow). (IHC stain) using DAP chromogen. 1000x

$\mathrm{E}$ : the islet of pancreas of diabetic animal shows a significant increase in the glucagon activity inside the Alpha cell (arrows). (IHC stain) using DAP chromogen. 1000x

F: section through islet of diabetic animal shows restored activity of the A cell after treatment with Rheum ribes extract (arrow) using (IHC stain) and DAP chromogen. 1000x 
Table 3: The effects of $200 \mathrm{mg} / \mathrm{kg}$ of Rhubarb (PO) on the histological changes of pancreas in normal and alloxan induced diabetic rats.

\begin{tabular}{|c|c|c|c|c|c|c|}
\hline & Control & $\begin{array}{c}D C \\
14 \text { days }\end{array}$ & $\begin{array}{c}D C \\
30 \text { days }\end{array}$ & $\begin{array}{c}\text { TD } \\
14 \text { days }\end{array}$ & $\begin{array}{c}\text { TND } \\
\text { 30days }\end{array}$ & $\begin{array}{c}\text { TD } \\
30 \text { day }\end{array}$ \\
\hline $\begin{array}{l}\text { BV.BM } \\
(\mu \mathrm{m})\end{array}$ & $\begin{array}{c}2.96 \\
\pm 0.26 \\
a\end{array}$ & $\begin{array}{c}5.58 \\
\pm 0.42 \\
C\end{array}$ & $\begin{array}{c}5.73 \\
\pm 0.30 \\
C\end{array}$ & $\begin{array}{c}4.25 \\
\pm 0.19 \\
\text { b }\end{array}$ & $\begin{array}{c}2.85 \\
\pm 0.19 \\
a\end{array}$ & $\begin{array}{c}3.93 \\
\pm 0.10 \\
a\end{array}$ \\
\hline $\begin{array}{l}\text { C.BM } \\
(\mu \mathrm{m})\end{array}$ & $\begin{array}{c}0.27 \\
\pm 0.01 \\
a\end{array}$ & $\begin{array}{c}0.68 \\
\pm 0.07 \\
b\end{array}$ & $\begin{array}{c}0.87 \\
\pm 0.10 \\
C\end{array}$ & $\begin{array}{c}0.42 \\
\pm 0.02 \\
a\end{array}$ & $\begin{array}{c}0.24 \\
\pm 0.01 \\
a\end{array}$ & $\begin{array}{c}0.38 \\
0.01 \\
a\end{array}$ \\
\hline B cell \% & $\begin{array}{c}71.15 \\
\pm 1.86 \\
a\end{array}$ & $\begin{array}{c}9.03 \\
\pm 1.52 \\
d\end{array}$ & $\begin{array}{c}7.88 \\
\pm 1.63 \\
\quad d\end{array}$ & $\begin{array}{c}46.65 \\
\pm 1.84 \\
\quad c\end{array}$ & $\begin{array}{c}69.68 \\
\pm 1.49 \\
a\end{array}$ & $\begin{array}{c}59.20 \\
\pm 2.43 \\
\text { b }\end{array}$ \\
\hline A cell \% & $\begin{array}{c}26.61 \\
\pm 1.59 \\
a\end{array}$ & $\begin{array}{c}86.33 \\
\pm 1.89 \\
\quad d\end{array}$ & $\begin{array}{c}87.53 \\
\pm 1.64 \\
\quad d\end{array}$ & $\begin{array}{c}49.40 \\
\pm 1.55 \\
\quad C\end{array}$ & $\begin{array}{c}27.78 \\
\pm 1.21 \\
a\end{array}$ & $\begin{array}{c}37.88 \\
\pm 2.27 \\
\text { b }\end{array}$ \\
\hline D cell \% & $\begin{array}{c}2.23 \\
\pm 0.39 \\
a\end{array}$ & $\begin{array}{c}4.63 \\
\pm 0.38 \\
C\end{array}$ & $\begin{array}{c}4.75 \\
\pm 0.35 \\
C\end{array}$ & $\begin{array}{c}3.95 \\
\pm 0.73 \\
b\end{array}$ & $\begin{array}{c}2.53 \\
\pm 0.47 \\
a\end{array}$ & $\begin{array}{c}3.08 \\
\pm 0.82 \\
b\end{array}$ \\
\hline IHC-insulin & $\begin{array}{c}61.16 \\
\pm 4.11 \\
a\end{array}$ & $\begin{array}{c}7.66 \\
\pm 0.66 \\
\quad C\end{array}$ & $\begin{array}{c}8.50 \\
\pm 0.76 \\
\quad C\end{array}$ & $\begin{array}{c}11.66 \\
\pm 0.88 \\
b\end{array}$ & $\begin{array}{c}58.83 \\
\pm 3.07 \\
\quad a\end{array}$ & $\begin{array}{c}17.50 \\
\pm 0.76 \\
b\end{array}$ \\
\hline IHC-glucagon & $\begin{array}{c}10.16 \\
\pm 1.24 \\
a\end{array}$ & $\begin{array}{c}58.33 \\
\pm 4.11 \\
\quad \text { C }\end{array}$ & $\begin{array}{c}65.00 \\
\pm 4.39 \\
\quad C\end{array}$ & $\begin{array}{c}30.00 \\
\pm 4.13 \\
\text { b }\end{array}$ & $\begin{array}{c}11.33 \\
\pm 1.81 \\
a\end{array}$ & $\begin{array}{c}28.33 \\
\pm 3.00 \\
b\end{array}$ \\
\hline
\end{tabular}

$\mathrm{C}=$ control, TND =Treated Non Diabetic Rats, $\mathrm{DC}=$ Diabetic Control, TD =Treated Diabetic Rats

Table 4: The effects of $100 \mathrm{mg} / \mathrm{kg}$ of Metformin on the histological changes of pancreas in normal and alloxan induced diabetic rats.

\begin{tabular}{|c|c|c|c|c|c|c|}
\hline & Control & $\begin{array}{c}D C \\
14 \text { days }\end{array}$ & $\begin{array}{c}D C \\
30 \text { days }\end{array}$ & $\begin{array}{c}\text { TD } \\
14 \text { days }\end{array}$ & $\begin{array}{c}\text { TND } \\
\text { 30days }\end{array}$ & $\begin{array}{c}\text { TD } \\
30 \text { day }\end{array}$ \\
\hline $\begin{array}{l}\text { BV.BM } \\
(\mu \mathrm{m})\end{array}$ & $\begin{array}{c}2.96 \\
\pm 0.26 \\
a\end{array}$ & $\begin{array}{c}5.58 \\
\pm 0.42 \\
C\end{array}$ & $\begin{array}{c}5.73 \\
\pm 0.30 \\
C\end{array}$ & $\begin{array}{c}3.95 \\
0.28 \\
b\end{array}$ & $\begin{array}{c}2.93 \\
0.12 \\
a\end{array}$ & $\begin{array}{c}3.35 \\
0.20 \\
a b\end{array}$ \\
\hline $\begin{array}{l}\text { C.BM } \\
(\mu \mathrm{m})\end{array}$ & $\begin{array}{c}0.27 \\
\pm 0.01 \\
a\end{array}$ & $\begin{array}{c}0.68 \\
\pm 0.07 \\
b\end{array}$ & $\begin{array}{c}0.87 \\
\pm 0.10 \\
c\end{array}$ & $\begin{array}{c}0.39 \\
0.02 \\
a\end{array}$ & $\begin{array}{c}0.23 \\
0.01 \\
a\end{array}$ & $\begin{array}{c}0.30 \\
0.01 \\
a\end{array}$ \\
\hline B cell $\%$ & $\begin{array}{c}71.15 \\
\pm 1.86 \\
a\end{array}$ & $\begin{array}{c}9.03 \\
\pm 1.52 \\
d\end{array}$ & $\begin{array}{c}7.88 \\
\pm 1.63 \\
d\end{array}$ & $\begin{array}{c}51.05 \\
2.66 \\
C\end{array}$ & $\begin{array}{c}71.65 \\
1.55 \\
a\end{array}$ & $\begin{array}{c}57.10 \\
2.07 \\
b\end{array}$ \\
\hline A cell \% & $\begin{array}{c}26.61 \\
\pm 1.59 \\
a\end{array}$ & $\begin{array}{c}86.33 \\
\pm 1.89 \\
d\end{array}$ & $\begin{array}{c}87.53 \\
\pm 1.64 \\
\quad d\end{array}$ & $\begin{array}{c}46.06 \\
2.52 \\
C\end{array}$ & $\begin{array}{c}27.61 \\
1.13 \\
a\end{array}$ & $\begin{array}{c}39.91 \\
2.03 \\
b\end{array}$ \\
\hline D cell \% & $\begin{array}{c}2.23 \\
\pm 0.39 \\
a\end{array}$ & $\begin{array}{c}4.63 \\
\pm 0.38 \\
b\end{array}$ & $\begin{array}{c}4.75 \\
\pm 0.35 \\
b\end{array}$ & $\begin{array}{c}3.58 \\
0.48 \\
a b\end{array}$ & $\begin{array}{c}2.40 \\
0.31 \\
a\end{array}$ & $\begin{array}{c}2.98 \\
0.89 \\
a\end{array}$ \\
\hline IHC-insulin & $\begin{array}{c}61.16 \\
\pm 4.11 \\
a\end{array}$ & $\begin{array}{c}7.66 \\
\pm 0.66 \\
b\end{array}$ & $\begin{array}{c}8.50 \\
\pm 0.76 \\
b\end{array}$ & $\begin{array}{c}12.00 \\
\pm 1.65 \\
b\end{array}$ & $\begin{array}{c}59.33 \\
\pm 3.92 \\
a\end{array}$ & $\begin{array}{c}16.00 \\
\pm 1.18 \\
b\end{array}$ \\
\hline IHC-glucagon & $\begin{array}{c}10.16 \\
\pm 1.24 \\
a\end{array}$ & $\begin{array}{c}58.33 \\
\pm 4.11 \\
\text { C }\end{array}$ & $\begin{array}{c}65.00 \\
\pm 4.39 \\
\text { C }\end{array}$ & $\begin{array}{c}34.00 \\
\pm 3.84 \\
b\end{array}$ & $\begin{array}{c}12.16 \\
\pm 1.42 \\
a\end{array}$ & $\begin{array}{c}33.83 \\
\pm 3.23 \\
b\end{array}$ \\
\hline
\end{tabular}

C = Control, TND = Treated Non Diabetic Rats, DC =Diabetic Control, TD =Treated Diabetic Rats. 


\section{Discussion}

In the present study, serum glucose levels in alloxan-induced diabetic rats were significantly increased at $14^{\text {th }}$ and $30^{\text {th }}$ days as compared to the control group. This result is in agreement with those of Lucchesi et al. (2015) and Dizaye et al. (2016). ${ }^{11,12}$ In this study, the elevation of blood glucose indicates that this effect is caused by the direct influence of alloxan on pancreatic Beta cells. Histological changes of pancreatic tissue include degranulation of Beta cells and significant reduction of the number of these cells in the islet of Langerhans, causing a defect or a decrease in the production and secretion of the insulin. On the other hand, a significant increase in the number of Alpha cells and Delta cells were seen, the latter changes further exacerbate the hyperglycemia induced by lack of insulin. Further histological changes were seen, including a significant increase in the thickness of the basement membrane in the blood vessels in the pancreas and capillaries of Langerhans islets, causing disturbing effects on the functions of the gland. In the present study, the level of serum amylase in alloxan-induced diabetic rats was significantly decreased at $14^{\text {th }}$ and $30^{\text {th }}$ days as compared to the control group. This result is in agreement with Eleazu et al. (2015) and Ebrahimi et al. (2016), who reported that the diabetic condition affects the function of the exocrine pancreas and the secretion of amylase is selectively impaired. ${ }^{13,14}$ In this study, the following reduction in amylase activity is a result of the impairment of pancreatic exocrine functions which may be due to insulin deficiency and relative glucagon predominance, as shown in histological finding of the pancreatic tissues by immunohistochemical techniques, which show a decrease in the activity of beta cell due to selective damage of pancreatic beta cells by alloxan and this is associated with a concomitant increase in the alpha cell activity. In the present study, a significant reduction in the blood glucose level was observed in diabetic rats treated with extract of Rheum ribes roots at $14^{\text {th }}$ and $30^{\text {th }}$ days as compared to the diabetic animals. This result is in agreement with the study of Raafat and El-Lakany (2017).15 The hypoglycemic effect of plant extract may be due to the presence of insulin-like substances in plants like Flavonoids or other materials that stimulate regeneration and reactivation of Beta cells to produce more insulin. This improvement is shown in histological results on pancreatic tissue by increasing the number of Beta cells which may permit recovery of partially destroyed Beta cells or may also have initiated cell proliferation, and observed a significant reduction in the number of Alpha and Delta cells as a result of regeneration of beta cells. By histological measurement of the thickness of basement membrane in the blood vessels of pancreas and capillaries in islet of Langerhans, there is a significant reduction due to substances like flavonoids which are frequently implicated as having antidiabetic effects and may lead to prevent or delays progression of microvascular changes, ${ }^{16}$ but these improvements did not lead to $100 \%$ recovery, and this is maybe due to the short duration of the treatment, or due to a little quantity of insulin-like materials in the plant which may need more time to become more effective. In the present study, a significant increase in the activity of serum amylase in diabetic rats at $14^{\text {th }}$ and $30^{\text {th }}$ days was observed after treatment with Rheum ribes, extracts as compared to the diabetic controls. These results may be due to the presence of pharmacologically active substances in plants that stimulate Beta-cells to produce more insulin and stimulate pancreatic exocrine function to secrete amylase. ${ }^{17}$ Histological findings of the pancreas by using immunohistochemical technique showed a significant increase in the activity of beta cells and a significant decrease in the activity of alpha cells. This result may be explained by the fact that these plants 
may contain insulin-like substances that stimulate islet cells in the pancreas, causing activation and regeneration of Beta cells. The surviving beta-cells regenerated and virtually regained their normal immunostaining and functional status for insulin. Mechanisms such as the stimulation or regeneration effects on beta cells or extrapancreatic effects are proposed for the hypoglycemic action of these plants. Metformin, similar to the Rhubarb extract, produced a significant increase in serum amylase levels of diabetic rats. However, a non significant difference in activity of beta cells and a significant decrease in alpha cell activity were observed in diabetic rats treated with Metformin using $\mathrm{IHC}$ technique on $14^{\text {th }}$ and $30^{\text {th }}$ days as compared to diabetic controls. Unlike this result, another study concluded that Metformin restores insulin secretion activities and protects pancreatic $\beta$ cells from lipotoxicity or glucotoxicity. ${ }^{18}$ This result indicates that Metformin did not affect on the regeneration of Beta cells. ${ }^{19}$ In this study, treated diabetic animals showed a significant increase in body weight on $30^{\text {th }}$ days of treatment with (Rheum ribes, compared with diabetic rats. The ability of the plant extracts to increase body weight seems to be due to its ability to repair the hepato-renal damage slightly, but no significant changes were observed on $14^{\text {th }}$ days (Rheum ribes, as compared to the diabetic controls. The results indicated that in order to return to normal or to improve weight loss, more time and more concentration of the plant extracts is requiring. In this study, no significant changes in biochemical and histological study were found in treated nondiabetic rats at $14^{\text {th }}$ and $30^{\text {th }}$ day's administration in groups (Rheum ribes, and metformin) when compared to the control group. These results indicate that the administration of Rheum ribes and metformin have no effect on biochemical and histological changes of healthy animals.

\section{Conclusion}

Daily administration of Rheum ribes significantly reduced blood glucose and caused a marked increase in the activity of Beta-cells followed by a decrease in the activity of Alpha-cells. The results of tissue structures and serum biochemical estimation indicated that the plant extract has regeneration and repair effects.

\section{Competing interests}

The authors declare no competing interests.

\section{References}

1. Patwardhan B, Partwardhan A. Traditional Medicine: Modern Approach for affordable global health: World Health Organization; 2005.

2. Bahmani M, Zargaran A, Rafieian-Kopaei M, Saki K. Ethnobotanical study of medicinal plants used in the management of diabetes mellitus in the Urmia, Northwest Iran. Asian Pac J Trop Biomed 2014; 7(Suppl 1):348-54.

3. Devonish JA, Singh S, Tomkinson E, Morse GD. Novel Considerations about Diabetes Management Strategies in Chinese Immigrants in America: Possible Corollaries of the Use of Traditional Chinese Medicines. Innov Pharm 2017; 8(2):1-22.

4. Qader G, Dizaye K,Mahwi T. Hypoglycemic, antihistaminic and diuretic effects of aqueous extract of Adiantum capillus. Iraqi Journal of Pharmacy 2011; 11(1):43-51.

5. Pang $B, N i Q$, Lin $Y Q$, Wang $Y T$, Zheng $Y J$, Zhao XM, et al. Traditional Chinese Patent Medicine for Treating Impaired Glucose Tolerance: A Systematic Review and Meta-Analysis of Randomized Controlled Trials. J Altern Complement Med 2018; 24(7):634-55.

6. Ozbek H, Ceylan E, Kara M, Ozgokce F, Koyuncu M. Hypoglycemic effect of Rheum ribes roots in alloxan induced diabetic and normal mice. Scand JLab Anim Sci 2004; 31(2):113-5.

7. Hosseini A, Mollazadeh H, Amiri MS, Sadeghnia $\mathrm{HR}$, Ghorbani A. Effects of a standardized extract of Rheum turkestanicum Janischew root on diabetic changes in the kidney, liver and heart of streptozotocin-induced diabetic rats. Biom Pharmacother 2017; 86:605-11.

8. Fueki T, Sumino M, Makino T, Matsuoka T, Beppu M, Tanaka K, et al. Quick and easy preparation method for decoctions of kampo formula (part 3): Extraction efficiency of the IPCD method for volatile compounds. Tradit Kampo Med 2016; 3(2):157-61.

9. Sultan AH, Dizaye KF, Banna HB. Histological, immunocytochemical and biochemical study of 
the effect of Adiantum capillus on alloxan induced diabetic rats. MEJIM 2012; 5(1):3-12.

10. Rodriguez-Calvo T, Zapardiel-Gonzalo J, Amirian N, Castillo E, Lajevardi Y, Krogvold L, et al. Increase in pancreatic proinsulin and preservation of beta cell mass in autoantibody positive donors prior to type 1 diabetes onset. Diabetes, 2017; 66(5):1334-45.

11. Dizaye KF, Ahmed AA. Renoprotective evaluations of different angiotensin inhibitors on diabetic nephropathy in Rats. MEJIM 2016; $9(3): 3-11$.

12. Lucchesi AN, Cassettari LL, Spadella CT. Alloxan-induced diabetes causes morphological and ultrastructural changes in rat liver that resemble the natural history of chronic fatty liver disease in humans. J Diabetes Res 2015; 2015:494578.

13. Ebrahimi E, Shirali S, Talaei R. The protective effect of marigold hydroalcoholic extract in STZ-induced diabetic rats: evaluation of cardiac and pancreatic biomarkers in the serum. J Bot 2016; 2016:1-6.

14. Eleazu C, Okafor P. Use of unripe plantain (Musa paradisiaca) in the management of diabetes and hepatic dysfunction in streptozotocin induced diabetes in rats. Interv Med Appl Sci 2015; 7(1):9 $-16$.

15. Raafat K, El-Lakany A. Combination of Rheum ribes and metformin against diabetes, thermal hyperalgesia, and tactile allodynia in a mice model. Altern Ther Health Med 2017; 23(7):13848.

16. Govindappa M. A review on role of plant (s) extracts and its phytochemicals for the management of diabetes. J Diabetes Metab 2015; 6(7):1-38.

17. Etxeberria U, de la Garza AL, Campión J, Martinez JA, Milagro FI. Antidiabetic effects of natural plant extracts via inhibition of carbohydrate hydrolysis enzymes with emphasis on pancreatic alpha amylase. Expert Opin Ther Targets 2012; 16(3):269-97.

18. Yang X, Xu Z, Zhang C, Cai Z, Zhang J. Metformin, beyond an insulin sensitizer, targeting heart and pancreatic $\beta$ cells. Biochim Biophys Acta Mol Basis Dis 2017; 1863(8):1984-90.

19. Saisho Y. Metformin and inflammation: its potential beyond glucose-lowering effect. Endocr Metab Immune Disorders Drug Targets 2015; 15(3):196-205. 